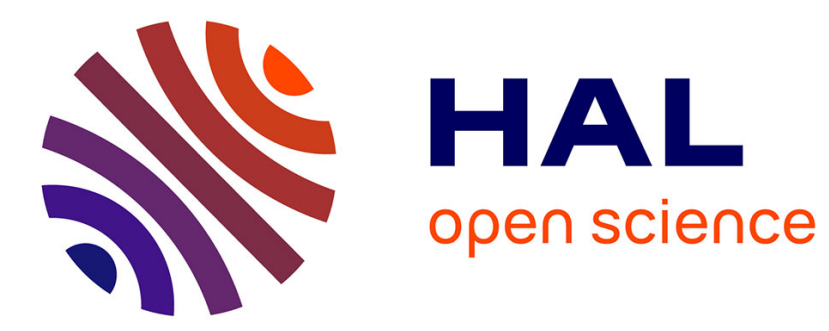

\title{
Polychlorinated biphenyls (PCBs) and their hydroxylated metabolites (OH-PCBs) in harbor seal () livers from San Francisco Bay, California and Gulf of Maine
}

June-Soo Park, Olga Ioanna Kalantzi, Dianne Kopec, Myrto Petreas

\section{To cite this version:}

June-Soo Park, Olga Ioanna Kalantzi, Dianne Kopec, Myrto Petreas. Polychlorinated biphenyls (PCBs) and their hydroxylated metabolites (OH-PCBs) in harbor seal () livers from San Francisco Bay, California and Gulf of Maine. Marine Environmental Research, 2009, 67 (3), pp.129. 10.1016/j.marenvres.2008.12.003 . hal-00563064

\section{HAL Id: hal-00563064 https://hal.science/hal-00563064}

Submitted on 4 Feb 2011

HAL is a multi-disciplinary open access archive for the deposit and dissemination of scientific research documents, whether they are published or not. The documents may come from teaching and research institutions in France or abroad, or from public or private research centers.
L'archive ouverte pluridisciplinaire HAL, est destinée au dépôt et à la diffusion de documents scientifiques de niveau recherche, publiés ou non, émanant des établissements d'enseignement et de recherche français ou étrangers, des laboratoires publics ou privés. 


\section{Accepted Manuscript}

Polychlorinated biphenyls (PCBs) and their hydroxylated metabolites (OHPCBs) in harbor seal (Phoca vitulina) livers from San Francisco Bay, California and Gulf of Maine

June-Soo Park, Olga Ioanna Kalantzi, Dianne Kopec, Myrto Petreas

PII:

S0141-1136(08)00251-1

DOI:

10.1016/j.marenvres.2008.12.003

Reference:

MERE 3308

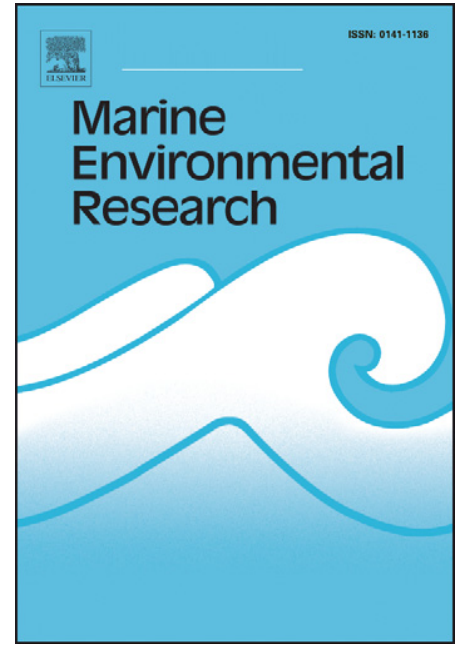

To appear in:

Marine Environmental Research

Received Date:

9 August 2007

Revised Date:

11 December 2008

Accepted Date:

12 December 2008

Please cite this article as: Park, J-S., Kalantzi, O.I., Kopec, D., Petreas, M., Polychlorinated biphenyls (PCBs) and their hydroxylated metabolites (OH-PCBs) in harbor seal (Phoca vitulina) livers from San Francisco Bay, California and Gulf of Maine, Marine Environmental Research (2008), doi: 10.1016/j.marenvres.2008.12.003

This is a PDF file of an unedited manuscript that has been accepted for publication. As a service to our customers we are providing this early version of the manuscript. The manuscript will undergo copyediting, typesetting, and review of the resulting proof before it is published in its final form. Please note that during the production process errors may be discovered which could affect the content, and all legal disclaimers that apply to the journal pertain. 
1 Polychlorinated biphenyls (PCBs) and their hydroxylated metabolites (OH-PCBs) in

2 harbor seal (Phoca vitulina) livers from San Francisco Bay, California and Gulf of

\section{Maine}

4

5

6

June-Soo Park ${ }^{1}$, Olga Ioanna Kalantzi ${ }^{1}$, Dianne Kopec ${ }^{2}$, Myrto Petreas ${ }^{1}$

7

$8{ }^{1}$ Department of Toxic Substances Control, California Environmental Protection Agency,

9 Berkeley, California 94710, USA; ${ }^{2}$ Department of Biological Sciences, University of

10 Maine, Orono, Maine 04469, USA

11

12

13

14

15

16

17

18

19

20

21

22

*Corresponding author. Email address: jpark@ dtsc.ca.gov (J.S. Park) 


\section{Abstract}

24 Bioaccumulation of endocrine disruptors in marine mammals positioned at the top of

25 the food chain is of toxicological concern. Stranded four pup and ten adult harbor seal

26 (Phoca vitulina) livers were collected from San Francisco Bay and the Gulf of Maine and

27 analyzed for polychlorinated biphenyls (PCBs) and their hydroxylated metabolites (OH-

28 PCBs). We used GC-ECD and GC-NCI/MS to investigate the presence of 28 PCBs and

298 OH-PCB metabolites, respectively. $\Sigma_{28} \mathrm{PCB}$ concentrations (di- to octa-CBs) ranged

30 from 1.81 to $35.9 \mu \mathrm{g} / \mathrm{g}$ lipid with a median of 6.53 for the seal pups and 2.31 to $249 \mu \mathrm{g} / \mathrm{g}$

31 lipid with a median of 28.9 for the adult seals. $\Sigma_{8} \mathrm{OH}-\mathrm{PCB}$ concentrations (penta- to

32 hepta-OH-PCBs) ranged from 0.02 to $0.69 \mu \mathrm{g} / \mathrm{g}$ lipid with a median of 0.04 for the adult

33 seals, i.e., at much lower concentrations than those for PCBs. Ratios of OH-PCBs to

34 PCBs $(0.24 \%$ on average) were comparable to those in beluga whale, but were lower than

35 ratios in human livers. The OH-PCB profiles were slightly different between SFB and

36 GOM seal livers although similar PCB congener patterns were observed. Generally, 4-

37 OH-CB107 was found predominantly in seal livers and was the only OH-PCB detectable

38 in most of seal pup livers. This study provides information on OH-PCBs in seals, adding

39 to the scarce exposure data for these chemicals.

40

41

42 Key words: hydroxylated PCB metabolites, polychlorinated biphenyls, harbor seal liver,

43 San Francisco Bay, Gulf of Maine 


\section{1. Introduction}

46 Polychlorinated biphenyls (PCBs) are known endocrine disruptors that are persistent

47 and lipophilic, and biomagnify through the food chain (Wan et al., 2005). Since marine

48 mammals such as seals are positioned at the top of the marine food web and have a

49 relatively long life span (25-30 years), they are exposed to organochlorines (Neale et al.,

50 2005a; Shaw et al., 2005) and are consequently vulnerable to endocrine disruptive effects

51 such as reproductive impairment (Reijnders, 1986; Reddy et al., 2001), cancer (Martineau

52 et al., 2002; Ylitalo, 2005), thyroid alteration (Sormo et al., 2005; Tabuchi et al., 2006),

53 and immune suppression/infectious diseases (Ross, 2002; Beckmen et al., 2003; Hall et

54 al., 2006; Hammond et al., 2005). PCBs are stored in the insulating blubber (lipid) and

55 can be subsequently remobilized to the blood through lipid metabolism during the

56 seasonal fasting (Debier et al., 2006), posing a health risk.

57 PCB metabolites; hydroxyl and methylsulfone PCBs (OH- and $\left.\mathrm{MeSO}_{2}-\mathrm{PCBs}\right)$ exert

58 similar toxicological effects to PCBs in mammals, particularly thyroid alteration in

59 laboratory rats (Meerts et al 2002), suggesting the need for their inclusion in risk

60 assessment studies. Marine mammals, including seals, are capable of producing

61 cytochrome P450 enzymes (Teramitsu et al., 2000) that biotransform PCBs to more

62 soluble/excretable forms, i.e., OH-PCBs. Accordingly, 837 mono OH-PCB congeners

63 can be theoretically formed in the body via the mechanisms of arene oxidation 1,2 shift

64 and/or direct oxygen insertion (Letcher et al., 2000). While most of the OH-PCBs tend to

65 be excreted (Letcher et al. 2000), some specific OH-PCBs have been retained

66 predominantly in the blood of humans (Fängström et al., 2002; Park et al., 2007a) and 
67 marine mammals (Hoekstra et al., 2003; Houde et al., 2006) due to their preferential

68 binding to blood proteins (Letcher et al. 2000). OH-PCBs are also retained in the livers

69 of rats (Bergman et al., 1994), humans (Guvenius et al., 2002), and beluga whales

70 (McKinney et al., 2006), presumably by mechanisms similar to pentachlorophenol

71 conjugation to liver fatty acids and/or liver protein/enzymes (Leighty and Fentiman,

72 1982). A set of structurally known OH-PCB metabolites preferentially retained in the

73 body have an $\mathrm{OH}$ - group bound to a para carbon of a phenyl ring and chlorine atoms

74 bound to carbon adjacent to the OH-group (Lans et al., 1993).

75 In this pilot research study we used liver samples collected from stranded, dead

76 harbor seals from San Francisco Bay (SFB) and from an island off the Gulf of Maine

77 (GOM). Although the causes of death of the harbor seals stranded on SFB and GOM

78 shores were not known, it is possible that liver accumulation of PCBs and their

79 metabolites may have contributed directly/indirectly to some causative effects, such as

80 infectious disease and liver dysfunction. Thus, the circulation and bioaccumulation of

81 these contaminants in the liver of seals is of concern.

82 Therefore, we investigated the distribution of possible PCB precursors and OH-PCB

83 metabolites retained in liver tissues of harbor seals stranded in the SFB and the GOM

84 coast where there are the scarce exposure data for OH PCBs in seals which often carry

85 high PCB body burden (tens of ppm). The present study was also undertaken to provide

86 data to compare contaminant exposure in other marine mammals and humans.

87

88

89 2. Materials and methods 


\section{$91 \quad$ 2.1. Seal liver tissue sampling}

93 Seal liver samples analyzed in this study were collected from SFB as part of a larger

94 study that examined harbor seal population dynamics, health, contaminant residues and

95 prey selection (Kopec and Harvey, 1995). Liver samples were collected from stranded,

96 dead harbor seals (Phoca vitulina) between 1989 and 1998 found along the shores SFB,

97 an urban/industrialized estuary that hosts a year-round resident population of about 500

98 harbor seals. Liver tissues were also collected from stranded harbor seals between 2002

99 and 2003 from Mt. Desert Rock, an isolated island 20 miles offshore of the central Maine

100 coast. Seals hauling at Mt. Desert Rock are part of the larger regional seal population in

101 the GOM numbering over 74,000 harbor seals. As a pilot study, a subset of four pup and

102 five adult seal livers from SFB and five male seal livers from GOM were included in the

103 present study and analyzed for $\mathrm{PCBs}$ and $\mathrm{OH}-\mathrm{PCB}$, as summarized in Table 1. All

104 harbor seal tissue collections were authorized by the National Marine Fisheries Service

105 (NMFS) in coordination with local stranding network facilities (College of the Atlantic,

106 Bar Harbor, Maine and Museum of Vertebrate Zoology, University of California,

107 Berkeley, California). SFB samples consisted of males and females while all GOM livers

108 were from males. All seal liver samples were collected during necropsy and were

109 immediately placed in clean vials (I-Chem) at $-20{ }^{\circ} \mathrm{C}$ prior to analysis (Kopec and Harvey,

110 1995). Seals were grouped by age class based on standard length (Bigg, 1969).

111

112 2.2. Chemicals and standards 
114 The following OH-PCB standards were purchased from Wellington Laboratory

115 (TerraChem Inc., USA) and used as reference standards for the identification and

116 quantification of the analytes: 2,3,3',4',5-pentachlorobiphenyl-4-ol (4-OH-CB107),

117 2,2',3,4',5,5'-hexachlorobiphenyl-4-ol (4-OH-CB146), 2,2',3',4,4',5-hexachlorobiphenyl-

118 3-ol (3'-OH-CB138), 2,2',3,3',4',5-hexachlorobiphenyl-4-ol （4'-OH-CB130),

$1192,2^{\prime}, 3,4^{\prime}, 5,5^{\prime}, 6$-heptachlorobiphenyl-4-ol $\quad$ (4-OH-CB187), 2,2', 3',4,4',5,5'-

120 heptachlorobiphenyl-3-ol (3'-OH-CB180), 2,2',3,3',4',5,5'-heptachlorobiphenyl-4-ol (4'-

121 OH-CB172). 2,2',4,4',5,5'-hexachlorobiphenyl-3-ol (3-OH-CB153) was provided by

122 Professor Åke Bergman (Stockholm University, Sweden). The numbering of PCBs and

$123 \mathrm{OH}-\mathrm{PCB}$ is based on that specified by Ballschmitter and Zell (1980) and Letcher et al

124 (2000), respectively. Internal surrogate standards for PCBs and OH-PCBs were CB-14,

12565 and 166 for PCBs and 4'-OH-CB159 for OH-PCBs. Injection standards for PCBs and

126 OH-PCB analyses were CB-30 and 204, and CB-209, respectively. Diazomethane was

127 synthesized in hexane by using N-nitroso-N-methylurea (Sigma-Aldrich, USA) as

128 described elsewhere (Sandau, 2000). Other chemicals and solvents used for the analysis

129 include dichloromethane and hexane (trace analysis, Burdick \& Jackson), methanol,

130 methyl-tert butyl ether, and water (HPLC grade, Fisher Sci., USA), 2-propanol (99.9\%,

131 pesticide grade, Fisher Sci., USA), hydrochloric acid, sulfuric acid (98\%), potassium

132 hydroxide, potassium chloride, sodium hydroxide, and ethyl alcohol (94-96\%, 200 proof)

133 (Fisher Sci., USA), silica (200-400 mesh) (Sigma-Aldrich, USA). Organics in Cod liver

134 Oil (SRM1588b, National Institute of Standards and Technology, Gaithersburg, MD) was

135 used as a standard reference material for PCB analysis. 


\section{7 \\ 2.3. Analysis and clean up}

139 The analyses were conducted at the ultra-clean laboratory of the Department of Toxic

140 Substances Control, Berkeley, CA. The analytical method was modified from analyses

141 of seal blubber (She et al., 2002) and blood serum (Park et al., 2007a). In summary, liver

142 samples (0.4-3 g) along with a method blank (sodium sulfate), and a standard reference

143 material (NIST 1588b) were homogenized, spiked with PCB and OH-PCB surrogate

144 standards (1-5 ng and $1 \mathrm{ng}$, respectively), and extracted with a mixture of methyl-tert-

145 butyl ether (MTBE):hexane (1:1, v/v) $(75 \mathrm{~mL})$ with 2-propanol $(10 \mathrm{~mL})$. The samples

146 went through two more extractions by successive shaking and centrifuging with

147 MTBE:hexane mixture. Lipid content was determined gravimetrically using 7\% (v/v) of

148 the extracts. The extracts were treated with $1 \% \mathrm{KCl}$ wash and $\mathrm{KOH}$ phase separation.

149 Only 7\% (v/v) of the organic extracts were used for the PCB analysis to avoid saturation

150 of the ECD. The phenolic compounds retained in the $\mathrm{KOH}$ solution were re-protonated

151 by using $2 \mathrm{M} \mathrm{HCl}(\mathrm{pH}<2)$, extracted with MTBE:hexane $(1: 9, \mathrm{v} / \mathrm{v})(4 \mathrm{~mL})$, and

152 derivatized overnight by using diazomethane. The organic extract was cleaned up by

153 using concentrated sulfuric acid (98\%). Further clean up and fractionation was

154 conducted on the Pasteur pipette column packed with acidic silica gel $(1: 2 \mathrm{w} / \mathrm{w}, 0.6 \mathrm{~g})$ and

155 activated silica $(0.4 \mathrm{~g})$. The columns were eluted with $5 \mathrm{~mL}$ hexane and then $10 \mathrm{~mL}$

156 dichloromethane:hexane (1:1). The OH-PCB derivatives were cleaned up with

157 concentrated sulfuric acid (98\%), followed by passing through a Pasteur pipette column 
158 packed with sulfuric acidic silica gel $(0.5 \mathrm{~g})$ and activated silica $(0.1 \mathrm{~g})$. Injection

159 standards were added before GC analysis.

160

161 2.4. Instruments

162

163 Twenty eight PCB congeners (CB-28, 49, 52, 56, 66, 70, 74, , 99, 101, 105, 110, 113 ,

$164118,137,138,146,153,156,157,170,177,180,183,187,189,190,194,203)$ were

165 analyzed on a Varian 3800 gas chromatograph (GC) with ${ }^{63} \mathrm{Ni}$ electron capture detection

166 (Varian Inc., Walnut Creek, CA) equipped with dual capillary columns; RTX-5MS (60m

$167 \times 0.25 \mathrm{~mm}$ i.d., $0.25 \mu \mathrm{m}$ thickness, Restek, Bellefonte, PA) and DB-XLB $(60 \mathrm{~m} \times 0.25$

$168 \mathrm{~mm}$ i.d., $0.25 \mu \mathrm{m}$ thickness, J\&W Scientific, Folsom, CA). Carrier and make up gases

169 were helium and nitrogen, respectively and set in constant flow mode. Injection ( $2 \mu \mathrm{L})$

170 was made in splitless mode with an injector temperature of $280{ }^{\circ} \mathrm{C}$. The initial GC

171 temperature was set to $80{ }^{\circ} \mathrm{C}$ and held for $1.6 \mathrm{~min}$ followed by a $15{ }^{\circ} \mathrm{C} / \mathrm{min}$ increase to

$172135{ }^{\circ} \mathrm{C}, 1{ }^{\circ} \mathrm{C} / \mathrm{min}$ to $261{ }^{\circ} \mathrm{C}, 3{ }^{\circ} \mathrm{C} / \mathrm{min}$ to $295{ }^{\circ} \mathrm{C}$ and $1{ }^{\circ} \mathrm{C} / \mathrm{min}$ to $300{ }^{\circ} \mathrm{C}$ held for $3.5 \mathrm{~min}$.

173 Post run was set to $320^{\circ} \mathrm{C}$ for $1 \mathrm{~min}$.

174 Eight $\mathrm{OH}-\mathrm{PCB}$ s were determined as methyl derivatives by using a Varian 3800 gas

175 chromatograph equipped with a 1200L mass spectrometer (MS) (Varian Inc., Walnut

176 Creek, CA. The MS was operated in negative chemical ionization (NCI) mode with

177 electron energy of $70 \mathrm{eV}$ and emission current of $300 \mu \mathrm{A}$ using selected ion monitoring

178 (SIM). The GC was equipped with a DB-5MS capillary column $(60 \mathrm{~m} \times 0.25 \mathrm{~mm}$ i.d.,

$1790.25 \mu \mathrm{m}$ thickness, J\&W Scientific, Folsom, CA, USA). Injection $(2 \mu \mathrm{L})$ was made in

180 split/splitless mode with an injector temperature of $250{ }^{\circ} \mathrm{C}$. The initial GC temperature 
181 was set to $80{ }^{\circ} \mathrm{C}$ and held for $2 \mathrm{~min}$ followed by a $50{ }^{\circ} \mathrm{C} / \mathrm{min}$ increase to $200{ }^{\circ} \mathrm{C}, 1{ }^{\circ} \mathrm{C} / \mathrm{min}$ 182 to $230{ }^{\circ} \mathrm{C}$, and $30{ }^{\circ} \mathrm{C} / \mathrm{min}$ to $300{ }^{\circ} \mathrm{C}$ and held for 4 min. Post run was set to $320{ }^{\circ} \mathrm{C}$ for 1

183 min. The temperatures for both ion source and quadrupole were set to $150{ }^{\circ} \mathrm{C}$. We

184 monitored the most intense ions, either molecular ion or fragmentation ion; [ $\left.\mathrm{M}^{-}\right]$for $4^{\prime}-$ $185 \mathrm{MeO}-\mathrm{CB} 159,\left[\left(\mathrm{M}+2-\mathrm{CH}_{3}\right)^{-}\right]$for 4-MeO-CB187 and 4'-MeO-CB172, and [(M-HCl) $\left.{ }^{-}\right]$or

$186\left[(\mathrm{M}+2-\mathrm{HCl})^{-}\right]$for the rest of the congeners. Carrier and reagent gases were helium and 187 methane, respectively.

189 2.5. Quantification and $Q A / Q C$

191 All glassware were washed, rinsed with acetone and hexane, and baked at $550{ }^{\circ} \mathrm{C}$ for 1928 hours. Each batch consisted of one procedural blank, one SRM, and six samples. The

193 five points of external calibration curves were used for the quantifications of PCBs and 194 OH-PCBs. CB-28, 49, 52,66, 70, 74, 101, 105, 110, 118, 138, 146, 153, 156, 157, 177, $195180,183,187$ and 194 were quantitated on the RTX-5MS column while CB-99, 170, 190, 196 199, and 203 were quantitated on the DB-XLB column. We tested precision for the PCB 197 and OH-PCB analytical methods as well as the gravimetric lipid determination by using 198 duplicate liver samples within and between batches. We tested accuracy by using the 199 SRM samples. Both precision and accuracy were within reasonable error ranges $( \pm 25 \%)$.

200 To monitor the performance of the experimental procedures, $2.00 \mathrm{ng}$ of 4'-OH-CB159, 201 which, to our knowledge, has not been detected in any animal liver to date, were added to 202 all samples. We derivatized OH-PCB standards simultaneously with the sample extracts 203 for more accurate quantification. Any values lower than the LOQ $(\sim 0.48 \mathrm{ng} / \mathrm{g}$ fat $)$ were 
204 replaced by LOQ/2 when calculating summary statistics. We conducted non-parametric 205 tests (e.g., Spearman correlation) for PCB and OH-PCB data to assess their relationships 206 by using Minitab statistical software.

207 The average ( \pm standard deviation) surrogate recoveries of CB-14, CB-65, and CB208166 for PCB analysis were $92 \pm 6 \%, 82 \pm 7 \%$, and $82 \pm 19 \%$, respectively. The recoveries 209 from Standard Reference Materials (SRM 1588b Organics in Cod Liver Oil) ranged from $21063 \%$ for CB-194 to $125 \%$ for CB-170. The average ( \pm standard deviation) recovery of

211 the OH-PCB surrogate (4'-OH-CB159) was $77 \pm 15 \%$.

212

\section{3. Results and discussion}

In Table 2 we report the ranges and medians of PCBs and OH-PCBs (on a lipid 217 weight basis) measured in harbor seal liver tissues for four pups and five adults from SFB 218 and five adult males from GOM.

$223 \mu \mathrm{g} / \mathrm{g}$ fat while adult seal livers showed a wider range $(2.31-249 \mu \mathrm{g} / \mathrm{g}$ fat $)$. Because of the

224 limited sample size we did not examine the impact of gender on SFB samples and 225 geographical comparisons. In other study, females tend to have lower contaminant 226 burdens than males since reproductively active females can transfer a significant portion 
227 of their PCB body burden to their offsprings through gestation or nursing (Neale et al.,

228 2005b). During the winter, GOM seals may migrate southward along the coast to

229 urban/industrialized areas (e.g., Massachusetts Bay) (Waring et al., 2006) where they

230 may be exposed to elevated PCB levels, while SFB seals reside in the Bay for most of the

231 time.

232 CB-153 was the primary congener in both SFB and GOM adult seal livers, 233 comprising 22 and $31 \%$ on average of $\Sigma_{28} \mathrm{PCBs}$, respectively (Table 2) and was a good

234 indicator for $\Sigma_{28} \mathrm{PCBs}(\mathrm{r}=0.98$, albeit the highest point was excluded). $\mathrm{CB}-153$ together 235 with CB-138, 187 , and 180 , comprised $67 \%$ and $66 \%$ on average of $\Sigma_{28} \mathrm{PCBs}$ in SFB and

236 GOM, respectively. The nine PCB congeners presented in Table 2 accounted for more 237 than $80 \%$ of $\Sigma_{28} \mathrm{PCBs}$ in SFB and GOM seal livers. The average concentrations of $238 \Sigma_{28} \mathrm{PCBs}$ measured in GOM harbor seal livers $(28.3 \mathrm{ug} / \mathrm{g}$ fat) were comparable to $239 \Sigma_{38}$ PCBs measured in beluga whale livers (31.9 ug/g fat) from the St. Lawrence River

240 (McKinney et al., 2006). Although the number of congeners measured was different

241 between the McKinney and our study, most PCB congeners predominantly found in the

242 liver matrices, as well as the sample collection time, overlapped. In our study, 8 out of

24314 seal livers (1 SFB male pup, 1 SFB female adult, 3 SFB male adults and 3 GOM male

244 adults) showed PCB levels within or exceeding the estimated threshold level for adverse

245 effects on immune/reproductive function $(17-77 \mu \mathrm{g} / \mathrm{g}$ blubber fat) in aquatic animals as

246 summarized elsewhere (Shaw et al., 2005). Seal liver (this study) and blubber PCB

247 concentrations (Park et al., unpublished data) showed correlation ( $r=0.77$ ), which is

248 consistent with other studies (Wolkers et al 2006). Thus, it is possible that some of the

249 stranded harbor seals, particularly one SFB seal pup with high PCB liver accumulation, 
250 might have suffered PCB-related adverse effects, such as infectious diseases and/or the

251 conditions of the animals presented in Table 1.

252

253 3.2. OH-PCB metabolites

254

255 Although literature searches indicated that most of the OH-PCBs are retained in blood,

256 we attempted to measure $\mathrm{OH}-\mathrm{PCB}$ in liver because major enzyme-mediated

257 biotransformation of PCBs occurs in the liver. OH-PCBs were detected in almost all

258 liver tissues of SFB and GOM harbor seals including SFB seal pups. 4-OH-CB107 was

259 detected in almost all samples, followed by 4-OH-CB187 (67\%), 4-OH-CB146 (60\%), 3'-

260 OH-CB138 (60\%), and 3-OH-CB153 (47\%). As shown in Figure 1, the two OH-PCB

261 chromatograms analyzed as MeO-PCBs were presented for one of the calibration

262 standards (top) and a SFB adult male seal liver (bottom). The standard chromatogram

263 indicates that our GC temperature program resolved the possible co-elutions (e.g., 3-OH-

264 CB153/4-OH-CB146, 3'-OH-CB138/4'-OH-CB130, and 3'-OH-CB180/4'-OH-CB172).

265 Several unidentified OH-PCB peaks were present in the SFB seal liver chromatogram.

266 Particularly, two peaks (a hexa and a hepta OH-PCB) observed between the peaks of 4'-

267 OH-CB159 (internal standard) and 3'-OH-CB180 were fairly notable. When these

268 unidentified $\mathrm{OH}-\mathrm{PCB}$ were quantified using response factors for 4-OH-CB107 and 4-

269 OH-CB187 standards representing each hydroxyl homologue group, they comprised 16-

$27027 \%$ (22\% on average) of $\Sigma \mathrm{OH}-\mathrm{PCB}$ ( 2 (sum of identified and unidentified).

271 The harbor seal liver concentrations of OH-PCB metabolites $(0.020 \sim 0.693 \mu \mathrm{g} / \mathrm{g}$ fat $)$

272 in this study had a wider range than what has been reported for humans $(0.007 \sim 0.175$ 
$273 \mu \mathrm{g} / \mathrm{g}$ fat) (Guvenius et al., 2002) and beluga whales $(<0.5-0.145 \mu \mathrm{g} / \mathrm{g}$ fat) (McKinney et

274 al., 2006) due to one extreme value. Excluding that value, the range narrowed

$275(0.020 \sim 0.064 \mu \mathrm{g} / \mathrm{g}$ fat $)$ to previously reported levels. The $\Sigma_{8} \mathrm{OH}-\mathrm{PCB}$ levels identified in

276 the harbor seals were much lower ( $\sim 0.59 \%$ of $\Sigma_{28} \mathrm{PCBs}, 0.24 \%$ on average) than those of

277 parent PCBs. It should be noted that the sums of 28 PCBs includes congeners which are

278 not precursors of $8 \mathrm{OH}-\mathrm{PCB}$ and that, in addition, the presence of many OH-PCB

279 congeners below the detection limits may bias their sum. These ratios were comparable

280 to data from beluga whales in St. Lawrence River, but they were lower than data in

281 human livers (usually between 1-10\%). It is possible that these lower ratios in marine

282 mammals relative to humans may be due to a reduced capacity in marine mammals to

283 metabolize PCBs, or a higher Phase II conjugation process which rapidly depletes $\mathrm{OH}-$

284 PCBs (McKinney et al., 2006). This $\mathrm{OH}-\mathrm{PCB} / \mathrm{PCB}$ ratio was even higher in human

285 blood (Park et al., 2007a,b) and marine mammal blood (Hoekstra et al., 2003; Houde et

286 al., 2006), indicating that OH-PCB metabolites preferentially bind to blood protein

287 relative to liver fatty acids and/or hepatic proteins and enzymes. Since we did not

288 measure lower chlorinated OH-PCBs (containing fewer than four chlorines) and also did

289 not include the ones detected but not identified, we may have underestimated the total

290 concentrations of OH-PCB metabolites in seal livers.

291 The OH-PCB profiles are presented in the bottom of Figure 2. This profile was

292 slightly different between SFB and GOM seal livers although similar PCB congener

293 patterns were observed in the two regions (Figure 2, top). This difference may result

294 from biological (e.g., nutritional/reproductive status, age, gender, polymorphism) and

295 environmental factors (e.g., temperature, migration) influencing enzyme activities and 
296 thereby metabolite formation in seals. For example, Wolkers et al. (2008) reported that

297 EROD activity negatively correlated to blubber content in seals, indicating contaminants

298 get mobilized from blubber during fasting, and possibly induce the Phase I and II enzyme

299 system. Seals also go through other seasonal lipid changes via molting and reproduction.

300 However, the contributions from other various OH-PCB exposure pathways including

301 diet intake/food chain accumulation (Campbell et al., 2003), and even the abiotic aquatic

302 environments (Ueno et al., 2007) are probably minor, as observed in a recent study

303 (Verreault et al., 2008).

304 Although the profiles of OH-PCB congeners varied from sample-to-sample, 4-OH-

305 CB107 was the dominant congener, similar to the results from the St. Lawrence River

306 beluga whales (McKinney et al., 2006). This was the only congener detected in three

307 SFB seal pup livers in this study, which raises concern due to its relationship to thyroid

308 dysfunction reported for the experimental rat fetus (Meerts et al., 2002). The known

309 possible PCB precursors (CB-118 and CB-105) of 4-OH-CB107 in animals (Letcher et

310 al., 2000) were also found in our samples, albeit they were not among the most dominant

311 congeners. With 3-OH-CB153, 4-OH-CB146, 3'-OH-CB138, and 4-OH-CB187, they

312 comprised 66 to $81 \%$ of $\Sigma O H-P C B s$ (identified and unidentified penta, hexa, and hepta

313 OH-PCBs). They are the OH-PCB congeners primarily found in the blood of humans

314 (Park et al., 2007a,b) and wildlife (Park et al., 2008) since their chemical structure

315 preferentially binds to the blood transthyretin (TTR) receptor protein. This binding

316 involves a hydroxyl group in either the para- or meta-position of a biphenyl ring,

317 adjacent to chlorine atoms on both sides (Lans et al., 1993; Letcher et al., 2000). This

318 also seems to apply to the seal liver matrix, indicating interaction of those OH-PCBs with 
319 liver enzyme/proteins as well as fatty acid conjugation. 4'-OH-CB130 was reported at

320 considerable levels in human livers (Guvenius et al., 2002) while it was not detected or

321 detected at trace levels in our seal livers.

322 The pairs of PCB precursors and respective OH-PCB metabolites were correlated.

323 Since correlations could be driven by a single extreme value, that value was removed and

324 the resulting unbiased correlations were: CB-153/3-OH-CB146 ( $r=0.67, \mathrm{p}<0.05)$, CB-

325 138/3-OH-CB138 (r=0.74, p<0.05), CB-187/4-OH-CB187 ( $\mathrm{r}=0.66, \mathrm{p}<0.05)$. However,

326 the pairs of CB-118/4-OH-CB107 and CB-105/4-OH-CB107 showed weaker correlations

327 ( $\mathrm{r}=0.24$ and 0.32 , respectively), possibly because 4-OH-CB107 is labile (Malmberg et al.

328 2004). In the body, PCBs are metabolized via the various transformation pathways

329 mediated by the cytochrome P450 enzyme series (CYP1A, CYP2B, CYP3A).

330 Preferential CYP450 enzyme mediated-metabolic capacity of marine mammals towards

331 OH-PCBs depends on the number and positioning of the chlorine atoms around the

332 biphenyl ring (Boon et al., 1997; Li et al., 2003; McKinney et al., 2004). For example,

333 CB-118 and 105, having only ortho- and meta-unsubstituted sites and one or fewer ortho-

$334 \mathrm{Cl}$ atoms, were subject to the CYP1A type enzyme-mediated metabolism, while CB-52,

33549,101 and 110, with meta- and para- vicinal H-atoms, were preferentially metabolized

336 by CYP2B or CYP3A types of enzymes

337 We here report several $\mathrm{OH}-\mathrm{PCB}$ s retained in harbor seal livers in quantifiable

338 amounts. This is one of a few studies available on OH-PCB metabolites detected in liver

339 tissues; rats (Bergman et al., 1994; Haraguchi et al., 1998), humans (Guvenius et al.,

340 2002), beluga whales (McKinney et al., 2006), glaucous gulls (Verreault et al., 2007),

341 polar bears (Gebbink et al., 2008), and predatory birds (Jaspers et al, 2008). Data on seal 
342 liver OH-PCB metabolites are especially valuable because of the difficulties in sampling,

343 the rarity of the sample itself, and the complexity of liver analyses for OH-PCB

344 metabolites.

345 There are no reports available to date on the toxicological index for hepatic OH-PCB

346 metabolites. However, due to their endocrine disrupting properties, they should be

347 included in the risk assessment of marine mammals' health.

350 4. Summary and conclusions

PCBs and $\mathrm{OH}-\mathrm{PCB}$ metabolites were detected in livers of harbor seals from both the

353 San Francisco Bay and the Gulf of Maine. OH-PCB metabolites were retained in seal

354 liver, albeit at lower $\mathrm{OH}-\mathrm{PCB}$ s to $\mathrm{PCBs}$ ratios compared to human liver, possibly due to a

355 lower metabolic expression of CYP enzymes. The OH-PCB profiles were slightly

356 different between SFB and GOM seal livers although similar PCB congener patterns

357 were observed between the two regions. In general, 4-OH-CB107 was detected

358 predominantly in seal livers and was the only OH-PCB detectable in most seal pup livers,

359 raising toxicological concerns. These results should be treated with caution, as they are

360 based on a small sample size. They do, however, highlight the need to include OH-PCB

361 metabolites in the risk assessment of marine mammals, due to their potential endocrine

362 disrupting properties. Further investigations are needed to better understand the

363 relationship between exposure to these endocrine disruptors and possible health effects in

364 seals. 


\section{Acknowledgement and disclaimer}

370 Department of Toxic Substances Control for their valuable analytical expertise. The 371 ideas and opinions expressed herein are those of the authors and do not necessarily reflect

372 the official position of the California Department of Toxic Substances Control.

373

374

\section{References}

376

Ballschmitter, K., Zell, M. 1980. Analysis of polychlorinated biphenyls (PCB) by glass capillary gas chromatography. Composition of technical Aroclor- and Chlophen-PCB mixtures. Fresenius' journal of analytical chemistry 302, 20-31.

Beckmen, K. B., Blake, J. E., Ylitalo, G. M., Stott, J. L., O'Hara, T. M., 2003. Organochlorine contaminant exposure and associations with hematological and humoral immune functional assays with dam age as a factor in free-ranging northern fur seal pups (Callorhinus ursinus). Marine Pollution Bulletin 46, 594-606.

Bergman, Å., Klassonwehler, E., Kuroki, H., 1994. Selective Retention of Hydroxylated Pcb Metabolites in Blood. Environmental Health Perspectives 102, 464-469.

Bigg, M. A., 1969. The harbour seal in British Columbia. Fish Res Board Canada, Bulletin 172. 33 pp. 
388

Boon, J. P., vanderMeer, J., Allchin, C. R., Law, R. J., Klunsoyr, J., Leonards, P. E. G., Spliid, H., StorrHansen, E., McKenzie, C., Wells, D. E., 1997. Concentrationdependent changes of PCB patterns in fish-eating mammals: Structural evidence for induction of cytochrome P450. Archives of Environmental Contamination and Toxicology 33, 298-311.

Campbell, L. M., Muir, D. C. G., Whittle, D. M., Backus, S., Norstrom, R. J., Fisk, A. T., 2003. Hydroxylated PCBs and other chlorinated phenolic compounds in lake trout (Salvelinus namaycush) blood plasma from the Great Lakes Region. Environmental Science and Technology 37, 1720-1725.

Debier, C., Chalon, C., Le Boeuf, B. J., de Tillesse, T., Larondelle, Y., Thome, J. P., 2006. Mobilization of PCBs from blubber to blood in northern elephant seals (Mirounga angustirostris) during the post-weaning fast. Aquatic Toxicology 80, 149-157.

Fängström, B., Athanasiadou, M., Grandjean, P., Weihe, P., Bergman, Å., 2002. Hydroxylated PCB metabolites and PCBs in serum from pregnant Faroese women. Environmental Health Perspectives 110, 895-899.

Gebbink, W. A., Sonne, C., Dietz, R., Kirkegaard, M., Riget, F. F., Born, E. W., Muir, D. C. G., Letcher, R. J., 2008. Tissue-specific congener composition of organohalogen and metabolite contaminants in East Greenland polar bears (Ursus maritimus). Environmental Pollution 152 (3), 621-629.

Guvenius, D. M., Hassanzadeh, P., Bergman, Å., Noren, K., 2002. Metabolites of polychlorinated biphenyls in human liver and adipose tissue. Environmental Toxicology and Chemistry 21, 2264-2269. 
410 Hall, A. J., Hugunin, K., Deaville, R., Law, R. J., Allchin, C. R., Jepson, P. D., 2006. The

411 risk of infection from polychlorinated biphenyl exposure in the harbor porpoise

412 (Phocoena phocoena): A case-control approach. Environmental Health Perspectives $413 \quad 114,704-711$.

414 Hammond, J. A., Hall, A. J., Dyrynda, E. A., 2005. Comparison of polychlorinated 415 biphenyl (PCB) induced effects on innate immune functions in harbor and grey seals. $416 \quad$ Aquatic Toxicology 74, 126-138.

417 Haraguchi, K., Kato, Y., Kimura, R., Masuda, Y., 1998. Hydroxylation and 418 methylthiolation of mono-ortho-substituted polychlorinated biphenyls in rats: 419 Identification of metabolites with tissue affinity. Chemical Research in Toxicology 11 $420 \quad$ (12), 1508-1515.

421 Hoekstra, P. F., Letcher, R. J., O'Hara, T. M., Backus, S. M., Solomon, K. R., Muir, D. C. 422 G., 2003. Hydroxylated and methylsulfone-containing metabolites of polychlorinated 423 biphenyls in the plasma and blubber of bowhead whales (Balaena mysticetus). 424 Environmental Toxicology and Chemistry 22, 2650-2658.

425 Houde, M., Pacepavicius, G., Wells, R. S., Fair, P. A., Letcher, R. J., Alaee, M., Bossart, 426 G. D., Hohn, A. A., Sweeney, J., Solomon, K. R., Muir, D. C. G., 2006. 427 Polychlorinated biphenyls and hydroxylated polychlorinated biphenyls in plasma of 428 bottlenose dolphins (Tursiops truncatus) from the Western Atlantic and the Gulf of 429 Mexico. Environmental Science and Technology 40, 5860-5866.

430 Jaspers, V. L. B., Dirtu, A. C., Eens, M., Neels, H., Covaci, A. 2008. Predatory bird 431 species show different patterns of hydroxylated polychlorinated biphenyls (HO-PCBs) 
and polychlorinated biphenyls (PCBs). Environmental Science and Technology 42,

$433 \quad 3465-3471$.

434 Kopec, A. D., Harvey, J. T., 1995. Toxic pollutants, health indices and population 435 dynamics of harbor seals in San Francisco Bay, 1989-1992. Moss Landing Marine 436 Laboratories Technical Report 96-4. Moss Landing, CA, pp. 168

437 Lans, M. C., Klassonwehler, E., Willemsen, M., Meussen, E., Safe, S., Brouwer, A., 1993. 438 Structure-dependent, competitive interaction of hydroxy-polychlorobiphenyls, 439 hydroxy-dibenzo-p-dioxins and hydroxy-dibenzofurans with human transthyretin. 440 Chemico-Biological Interactions 88, 7-21.

441 Leighty, E. G., Fentiman, A. F., 1982. Conjugation of pentachlorophenol to palmitic acid 442 by liver-microsomes. Bulletin of Environmental Contamination and Toxicology 28, $443 \quad 329-333$.

444 Letcher, R. J., Klasson, W. E., Bergman, A., 2000. Methylsulfon and hydroxylated 445 metabolites of polychlorinated biphenyls. In: Handbook of Environmental Chemistry. 446 New Types of Persistent Halogenated Compounds, Vol. 3, Part K (Paasivirta J, ed). 447 Berlin: Springer-Verlag.

448 Li, H. X., Boon, J. P., Lewis, W. E., van den Berg, M., Nyman, M., Letcher, R. J., 2003.

449 Hepatic microsomal cytochrome P450 enzyme activity in relation to in vitro 450 metabolism/inhibition of polychlorinated biphenyls and testosterone in Baltic grey 451 seal (Halichoerus grypus). Environmental Toxicology and Chemistry 22, 636-644.

452 Malmberg, T., Hoogstraate, J., Bergman, Å., Wehler, E. K., 2004. Pharmacokinetics of 453 two major hydroxylated polychlorinated biphenyl metabolites with specific retention 454 in rat blood. Xenobiotica 34, 581-589. 
455 Martineau, D., Lemberger, K., Dallaire, A., Labelle, P., Lipscomb, T. P., Michel, P.,

456 Mikaelian, I., 2002. Cancer in wildlife, a case study: Beluga from the St. Lawrence

457 estuary, Quebec, Canada. Environmental Health Perspectives 110, 285-292.

458 McKinney, M. A., Arukwe, A., De Guise, S., Martineau, D., Beland, P., Dallaire, A., Lair,

459 S., Lebeuf, M., Letcher, R. J., 2004. Characterization and profiling of hepatic

460 cytochromes P450 and phase II xenobiotic-metabolizing enzymes in beluga whales

461 (Delphinapterus leucas) from the St. Lawrence River Estuary and the Canadian

$462 \quad$ Arctic. Aquatic Toxicology 69, 35-49.

463 McKinney, M. A., De Guise, S., Martineau, D., Beland, P., Lebeuf, M., Letcher, R. J.,

464 2006. Organohalogen contaminants and metabolites in beluga whale (Delphinapterus

465 leucas) liver from two Canadian populations. Environmental Toxicology and 466 Chemistry 25, 1246-1257.

467 Meerts, I., Assink, Y., Cenijn, P. H., van den Berg, J. H. J., Weijers, B. M., Bergman, Å.,

468 Koeman, J. H., Brouwer, A., 2002. Placental transfer of a hydroxylated 469 polychlorinated biphenyl and effects on fetal and maternal thyroid hormone 470 homeostasis in the rat. Toxicological Sciences 68, 361-371.

471 Neale, J. C. C., Gulland, F. M. D., Schmelzer, K. R., Harvey, J. T., Berg, E. A., Allen, S.

472 G., Greig, D. J., Grigg, E. K., Tjeerdema, R. S., 2005a. Contaminant loads and 473 hematological correlates in the harbor seal (Phoca vitulina) of San Francisco Bay, 474 California. Journal of Toxicology and Environmental Health-Part a-Current Issues 68, $475 \quad$ 617-633.

476 Neale, J. C. C., Schmelzer, K. R., Gulland, F. M. D., Berg, E. A., Tjeerdema, R. S., 477 2005b. Rapid communication: Organohalogen levels in harbor seal (Phoca vitulina) 
pups increase with duration of nursing. Journal of Toxicology and Environmental

479 Health-Part a-Current Issues 68, 687-691.

480 Park, J. S., Linderholm, L., Charles, M. J., Athanasiadou, M., Petrik, J., Kocan, A.,

481 Drobna, B., Trnovec, T., Bergman, Å., Hertz-Picciotto, I., 2007a. Polychlorinated

482 biphenyls and their hydroxylated metabolites (OH-PCBs) in pregnant women from

483 eastern Slovakia. Environmental Health Perspectives 115, 20-27.

484 Park, J. S., Petreas, M., Cohn, B. A., Factor-Litvak, P., 2007b. Measurement of

485 hydroxylated PCB metabolites (OH-PCBs) in archived serum from 1950-60's

486 California mothers. Organohalogen Compounds 69, 754-757.

487 Park, J. S., Holden, A., Wang, Y., Chang, J., Heckly, S., McKeown, K., Jewell, N.,

488 Hooper, K., 2008. Hydroxylated metabolites of polychlorinated biphenyls (PCBs) in

489 California wild birds. Organohalogen Compounds 70, 157-160.

490 Reddy, M. L., Reif, J. S., Bachand, A., Ridgway, S. H., 2001. Opportunities for using

491 Navy marine mammals to explore associations between organochlorine contaminants

492 and unfavorable effects on reproduction. Science of the Total Environment 274, 171-

$493 \quad 182$.

494 Reijnders, P. J. H. 1986. Reproductive failure in common seals feeding on fish from 495 polluted coastal waters. Nature 324: 456-457.

496 Ross, P. S. 2002. The role of immunotoxic environmental contaminants in facilitating the

497 emergence of infectious diseases in marine mammals. Human and Ecological Risk

498 Assessment 8: 277-292.

499 Sandau, C. D. 2000. Analytical chemistry of hydroxylated metabolites of PCBs and other 500 halogenated phenolic compounds in blood and their relationship to thyroid hormone 
and retinol homeostasis in humans and polar bears. Carleton University, Ottawa,

502 Ontario, Canada. Ph.D. Dissertation: pp 39-44.

503 Shaw, S. D., Brenner, D., Bourakovsky, A., Mahaffey, C. A., Perkins, C. R., 2005.

504 Polychlorinated biphenyls and chlorinated pesticides in harbor seals (Phoca vitulina

505 concolor) from the northwestern Atlantic coast. Marine Pollution Bulletin 50, 1069-

$506 \quad 1084$.

507 She, J. W., Petreas, M., Winkler, J., Visita, P., McKinney, M. and Kopec, D., 2002.

508 PBDEs in the San Francisco Bay Area: measurements in harbor seal blubber and

509 human breast adipose tissue. Chemosphere 46, 697-707.

510 Sormo, E. G., Jussi, I., Jussi, M., Braathen, M., Skaare, J. U., Jenssen, B. M., 2005.

511 Thyroid hormone status in gray seal (Halichoerus grypus) pups from the Baltic Sea

512 and the Atlantic Ocean in relation to organochlorine pollutants. Environmental

$513 \quad$ Toxicology and Chemistry 24, 610-616.

514 Tabuchi, M., Veldhoen, A., Dangerfield, N., Jeffries, S., Helbing, C. C., Ross, P. S., 2006.

515 PCB-related alteration of thyroid hormones and thyroid hormone receptor gene

516 expression in free-ranging Harbor seals (Phoca vitulina). Environmental Health

517 Perspectives 114, 1024-1031.

518 Teramitsu, I., Yamamoto, Y., Chiba, I., Iwata, H., Tanabe, S., Fujise, Y., Kazusaka, A.,

519 Akahori, F., Fujita, S., 2000. Identification of novel cytochrome P450 1A genes from

$520 \quad$ five marine mammal species. Aquatic Toxicology 51, 145-153.

521 Ueno, D., Darling, C., Alaee, M., Campbell, L., Pacepavicius, G., Teixeira, C., Muir, D.,

522 2007. Detection of hydroxylated polychlorinated biphenyls (OH-PCBs) in the abiotic 
environment: Surface water and precipitation from Ontario, Canada. Environmental

$524 \quad$ Science and Technology 41, 1841-1848.

525 Verreault, J., Dietz, R., Sonne, C., Gebbink, W. A., Shahmiri, S., Letcher, R. J., 2008.

526 Comparative fate of organohalogen contaminants in two top carnivores in Greenland:

527 Captive sledge dogs and wild polar bears. Comparative Chemistry and Physiology -

528 Toxicology and Pharmacology 147 (3), 306-315.

529 Verreault, J., Shahmiri, S., Gabrielsen, G. W., Letcher, R.J., 2007. Organohalogen and

530 metabolically-derived contaminants and associations with whole body constituents in

$531 \quad$ Norwegian Arctic glaucous gulls. Environment International 33 (6), 823-830.

532 Wan, Y., Hu, J. Y., Yang, M., An, L. H., An, W., Jin, X. H., Hattori, T., Itoh, M., 2005.

533 Characterization of trophic transfer for polychlorinated dibenzo-p-dioxins,

534 dibenzofurans, non- and mono-ortho polychlorinated biphenyls in the marine food

535 web of Bohai Bay, north China. Environmental Science and Technology 39, 24175362425.

537 Waring, G.T., Gilbert, J.R., Loftin, J., Cabana, N., 2006. Short-term movements of radio538 tagged harbor seals in New England. Northeastern Naturalist 13, 1-14.

539 Wolkers, H., Hammill, M. O., van Bavel, B., 2006. Tissue-specific accumulation and 540 lactational transfer of polychlorinated biphenyls, chlorinated pesticides, and 541 brominated flame retardants in hooded seals (Cistophora cristata) from the Gulf of St. 542 Lawrence: Applications for monitoring. Environmental Pollution 142 (3), 476-486.

543 Wolkers, H., Krafft B.A., van Bavel B., Helgason L. B., Lydersen C., Kovacs K.M. 2008.

544 Biomarker responses and decreasing contaminant levels in ringed seals (Pusa hispida) 
545 from Svalbard, Norway. Journal of Toxicology and Environmental Health: Part A $546 \quad 71(15), 1009-1018$.

547 Ylitalo, G. M. 2005. The role of organochlorines in cancer-associated mortality in 548 California sea lions (Zalophus californianus). Marine Pollution Bulletin 50, 30-39.

549 
Table 1

551 Information of seal liver samples collected from San Francisco Bay (SFB) and Gulf of Maine (GOM)

\begin{tabular}{|c|c|c|c|c|c|c|}
\hline $\begin{array}{l}\text { Collection } \\
\text { ID\# }\end{array}$ & Area & Age & Sex & Condition & $\begin{array}{l}\text { Season } \\
\text { Collected }\end{array}$ & Stranding Location \\
\hline AP01524 & SFB & Fetus & $\mathrm{F}$ & poor & spring & Tiburon, SFB, \\
\hline AP01531 & SFB & Pup & $\mathrm{F}$ & poor & spring & Yerba Buena Island, SFB \\
\hline AP01528 & SFB & Fetus & $M$ & poor & spring & Fremont, SFB \\
\hline AP01530 & SFB & Pup & $M$ & good & spring & Berkeley, SFB \\
\hline AP01527 & SFB & $A D$ & $\mathrm{~F}$ & poor & fall & East Palo Alto, SFB \\
\hline AP01526 & SFB & $A D$ & $\mathrm{~F}$ & excellent & spring & Redwood Creek, SFB \\
\hline AP01529 & SFB & $A D$ & $M$ & good & spring & Alameda, SFB \\
\hline AP01523 & SFB & $A D$ & $M$ & good & spring & $\begin{array}{l}\text { Marin Co. coast } \\
\text { (previously captured in SFB) }\end{array}$ \\
\hline AP01525 & SFB & $A D$ & $M$ & good & fall & San Francisco, SFB \\
\hline AP01533 & $M E$ & $A D$ & $M$ & good & summer & Mount Desert Rock, Maine \\
\hline AP01536 & $M E$ & $A D$ & $M$ & good & summer & Mount Desert Rock, Maine \\
\hline AP01535 & $M E$ & $A D$ & $M$ & moderate & summer & Mount Desert Rock, Maine \\
\hline AP01534 & $M E$ & $A D$ & $M$ & moderate & summer & Mount Desert Rock, Maine \\
\hline AP01537 & $M E$ & $A D$ & $M$ & excellent & summer & Mount Desert Rock Maine \\
\hline
\end{tabular}

552 *length $(\mathrm{cm}) /$ weight $(\mathrm{kg})$ to roughly quantify blubber thickness and general health. 
Table 2

554 Concentrations of PCBs and OH-PCBs measured from livers of dead and stranded harbor seals along San

555 Francisco Bay (SFB) and Gulf of Maine (GOM)

\begin{tabular}{|c|c|c|c|c|c|c|c|c|c|}
\hline & \multicolumn{6}{|c|}{ San Francisco Bay Seals } & \multirow{2}{*}{\multicolumn{3}{|c|}{$\begin{array}{c}\text { Gulf of Maine Seals } \\
\text { Adults }(\mathrm{N}=5)\end{array}$}} \\
\hline & \multicolumn{3}{|c|}{ Pups $(N=4)$} & \multicolumn{3}{|c|}{ Adults $(\mathrm{N}=5)$} & & & \\
\hline & $\min$ & $\max$ & median & $\min$ & $\max$ & median & $\min$ & $\max$ & median \\
\hline \multicolumn{10}{|l|}{ PCBs $(\mu g / g$ lipid $)$} \\
\hline PCB 118 & 0.02 & 0.48 & 0.07 & 0.03 & 0.32 & 0.17 & 0.03 & 0.19 & 0.08 \\
\hline PCB146 & 0.03 & 1.52 & 0.24 & 0.05 & 8.88 & 1.36 & 0.24 & 2.84 & 0.89 \\
\hline PCB 153 & 0.18 & 8.58 & 1.32 & 0.24 & 67.3 & 9.26 & 1.45 & 22.2 & 7.27 \\
\hline PCB 105 & 0.001 & 0.15 & 0.03 & 0.01 & 0.12 & 0.06 & 0.003 & 0.07 & 0.04 \\
\hline PCB138 & 0.16 & 6.13 & 0.97 & 0.23 & 38.9 & 5.39 & 1.09 & 13.5 & 4.23 \\
\hline PCB 187 & 0.09 & 3.45 & 0.68 & 0.62 & 38.6 & 4.53 & 0.37 & 6.73 & 2.25 \\
\hline PCB 183 & 0.04 & 1.37 & 0.22 & 0.06 & 9.77 & 1.23 & 0.18 & 1.99 & 0.69 \\
\hline PCB180 & 0.11 & 4.00 & 0.60 & 0.15 & 42.3 & 3.86 & 0.39 & 4.58 & 2.39 \\
\hline PCB 170 & 0.04 & 1.72 & 0.39 & 0.07 & 10.0 & 1.40 & 0.29 & 2.22 & 0.83 \\
\hline$\Sigma_{28}$ PCBs & 1.81 & 35.9 & 6.53 & 2.31 & 249 & 35.6 & 5.60 & 63.7 & 22.4 \\
\hline \multicolumn{10}{|l|}{ OH-PCBs ( $\mu g / g$ lipid $)$} \\
\hline 4-OH-CB107 & $<0.001$ & 0.018 & 0.004 & $<0.001$ & 0.123 & 0.026 & 0.008 & 0.033 & 0.017 \\
\hline 3-OH-CB153 & $<0.001$ & $<0.001$ & $<0.001$ & $<0.001$ & 0.036 & $<0.001$ & $<0.001$ & 0.006 & 0.002 \\
\hline 4-OH-CB146 & $<0.001$ & $<0.001$ & $<0.001$ & $<0.001$ & 0.218 & 0.002 & 0.003 & 0.018 & 0.008 \\
\hline 3'-OH-CB138 & $<0.001$ & 0.003 & $<0.001$ & $<0.001$ & 0.104 & $<0.001$ & 0.002 & 0.013 & 0.005 \\
\hline 4'-OH-CB130 & $<0.001$ & 0.001 & $<0.001$ & $<0.001$ & 0.034 & $<0.001$ & $<0.001$ & 0.002 & $<0.001$ \\
\hline 4-OH-CB 187 & $<0.001$ & 0.011 & $<0.001$ & 0.013 & 0.149 & 0.019 & 0.004 & 0.019 & 0.008 \\
\hline 3'-OH-CB180 & $<0.001$ & $<0.001$ & $<0.001$ & $<0.001$ & 0.017 & $<0.001$ & $<0.001$ & $<0.001$ & $<0.001$ \\
\hline 4'-OH-CB172 & $<0.001$ & $<0.001$ & $<0.001$ & $<0.001$ & 0.011 & $<0.001$ & $<0.001$ & $<0.001$ & $<0.001$ \\
\hline$\Sigma_{8} \mathrm{OH}-\mathrm{PCBs}$ & 0.004 & 0.034 & 0.004 & 0.017 & 0.693 & 0.045 & 0.019 & 0.064 & 0.045 \\
\hline
\end{tabular}




\section{Figure captions}

Fig. 1. GC chromatograms of calibration standard (top) and identified and unidentified OH-PCB metabolites from an adult harbor seal liver collected from San Francisco Bay (SFB) (bottom).

Fig. 2. Profiles of PCB precursors (top) and OH-PCB metabolites (bottom) observed in adult harbor seal livers from San Francisco Bay (SFB) and Gulf of Maine (GOM). Error bars indicate standard errors. 


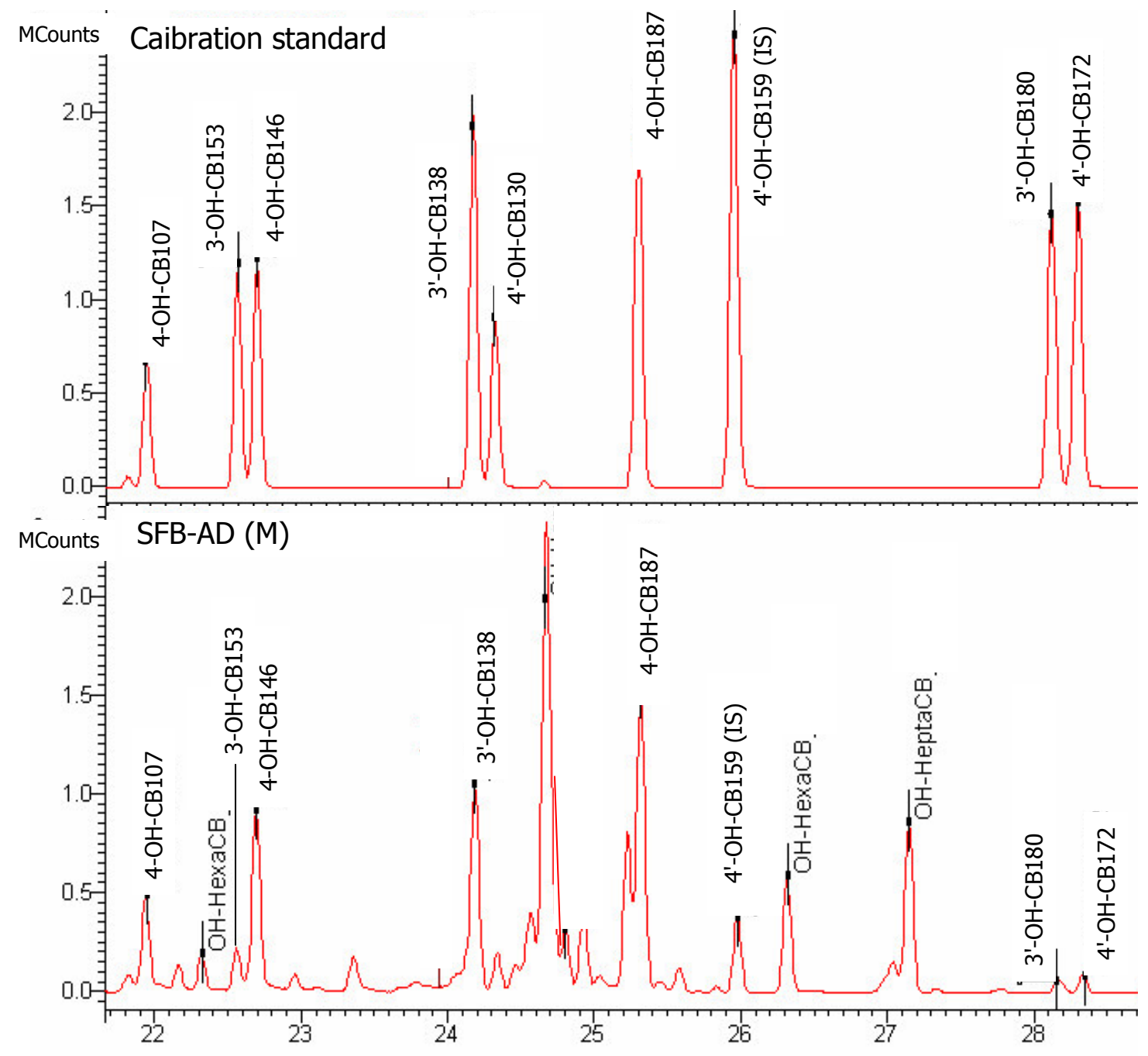



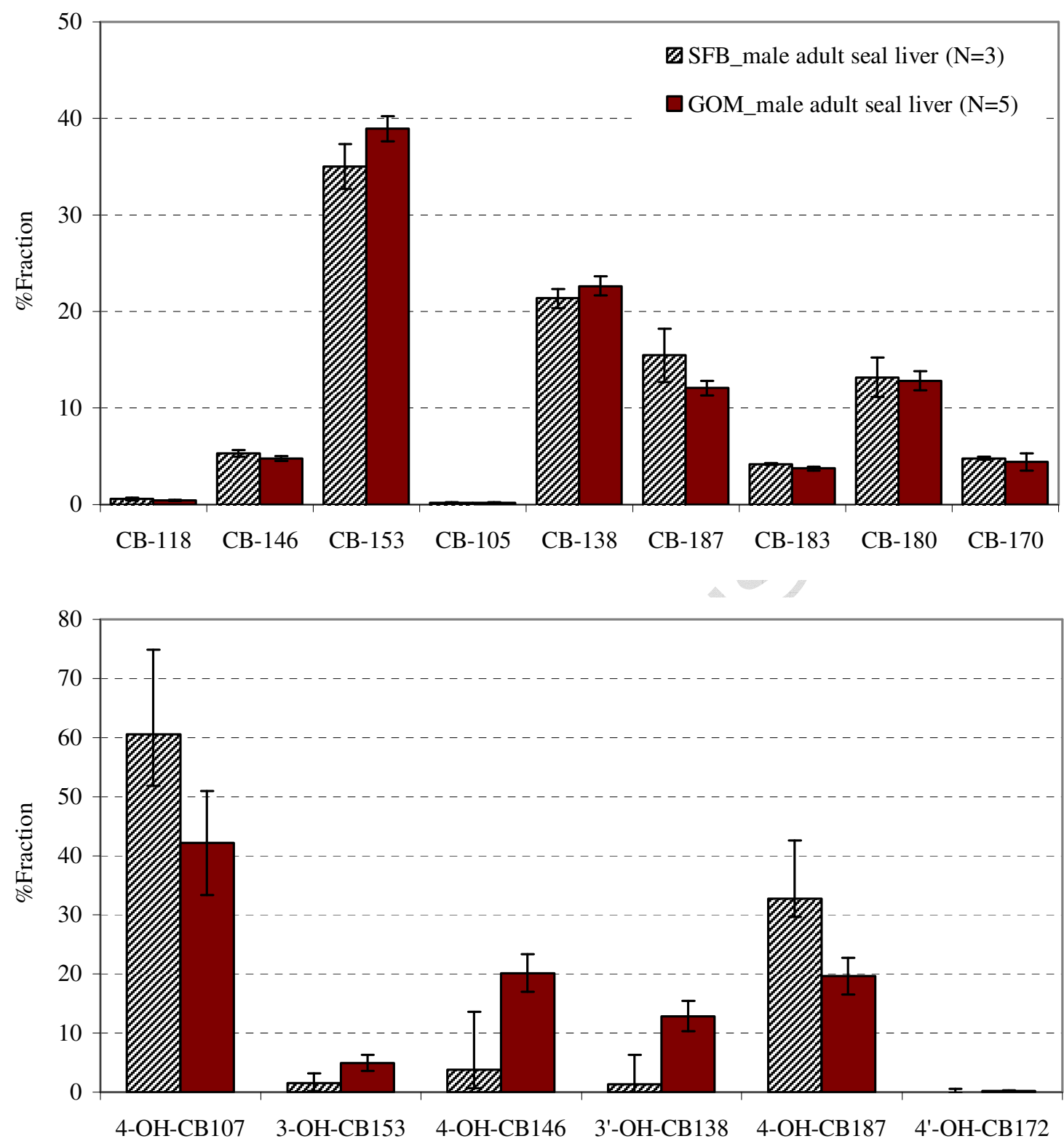